\title{
Political and Civic Engagement and Participation: Towards an Integrative Perspective ${ }^{1}$
}

\author{
MARTYN BARRETT * \& IAN BRUNTON-SMITH ** \\ * School of Psychology, University of Surrey, UK; ${ }^{* *}$ Department of Sociology, University of Surrey, UK \\ Correspondence Address: Martyn Barrett, Department of Psychology, University of Surrey, Guildford, Surrey \\ GU2 7XH, UK. Email: m.barrett@surrey.ac.uk
}

\begin{abstract}
This article presents an overview of current understandings in the study of political and civic engagement and participation, drawing in particular on innovations which have emerged from the PIDOP project. For the purposes of the article, 'engagement' is defined as having an interest in, paying attention to, or having knowledge, beliefs, opinions, attitudes or feelings about either political or civic matters, whereas 'participation' is defined in terms of political and civic participatory behaviours. The different forms that political and civic engagement and participation can take are outlined, and the factors that are related to different patterns of engagement and participation are reviewed. These factors operate at different levels, and include distal macro contextual factors, demographic factors, proximal social factors and endogenous psychological factors. An integrative model covering all four levels of factors is outlined. Some findings from the secondary analysis of existing datasets (including the European Social Survey and the International Social Survey Programme) in the PIDOP project are also reported. These findings show that engagement and participation vary as a function of complex interactions between macro, demographic and psychological factors. It is argued that multi-level integrative theories, such as the one proposed in the current article, are required to understand the drivers of political and civic engagement and participation, and that policies and interventions aimed at enhancing citizens' levels of engagement and participation need to take this multi-level complexity into account.
\end{abstract}

KEY WORDS: Political participation, civic participation, macro contextual factors, demographic factors, psychological factors

This article reports some of the theoretical understandings and empirical findings which have emerged from the Processes Influencing Democratic Ownership and Participation (PIDOP) project. This research project, which was funded by the European Commission under the Seventh Framework Programme, investigated political and civic engagement and participation in nine European countries. ${ }^{2}$

A conceptual distinction was drawn in the project between political and civic participation. The term 'political participation' was used to refer to activity that has the intent or effect of influencing either regional, national or supranational governance, either directly by affecting the making or implementation of public policy or indirectly by influencing the selection of individuals who make that policy (definition adapted from Verba, Schlozman \& Brady, 1995). By contrast, the term 'civic participation' was used to refer to voluntary activity focused on helping others, achieving a public good or solving a community problem, including work undertaken either alone or in cooperation with others in order to effect change (definition adapted from Zukin, Keeter, Andolina, Jenkins \& Delli Carpini, 2006).

A further conceptual distinction was drawn between 'participation' and 'engagement'. 'Participation' was construed as being behavioural in nature and so the term was used to refer to participatory behaviours. By contrast, 'engagement' was construed in psychological rather 
than behavioural terms and was used to denote having an interest in, paying attention to, or having knowledge, beliefs, opinions, attitudes or feelings about either political or civic matters.

This article falls into two main sections. The first section outlines the various forms that political and civic engagement and participation can take, and provides a review of the numerous macro, demographic, social and psychological factors that can drive political and civic engagement and participation. This first section is based upon findings that have been reported in the existing research literature. The second section of the article provides a summary of some findings which have emerged from the secondary analysis of existing datasets in the PIDOP project. The second section thus reports original findings from the project.

\section{A Review of Existing Findings in the Research Literature}

\section{The Different Forms of Political and Civic Engagement and Participation}

Political participation takes a number of different forms, including both conventional forms which involve electoral processes (e.g., voting, election campaigning, etc.) and nonconventional forms which occur outside electoral processes (e.g., signing petitions, participating in political demonstrations, etc.). Civic participation also entails diverse types of activities, including working collectively to solve community problems, belonging to community organizations, attending meetings about issues of concern, volunteering, making donations to charities, etc. Likewise, engagement involves a range of different forms, including paying attention to the news media (newspapers, magazines, television, radio, internet), having political or civic knowledge or beliefs, understanding political or civic values, and holding opinions about and attitudes towards political or civic matters.

Table 1 lists the numerous forms that political and civic participation and engagement may take. It should be noted that participation and engagement may be exhibited in relationship to a number of different community and institutional levels, including the local, municipal, regional, national, transnational and supranational level. It is important to acknowledge this wide range of forms and levels if the goal is to obtain an accurate understanding of people's actual patterns of engagement and participation. This is because the exclusion of particular forms will lead to underestimations, especially among particular sub-groups. For example, excluding translation activities and transnational remittances is likely to lead to the underestimation of levels of participation among minority and migrant groups (Stepick, Stepick \& Labissiere, 2008; Vertovec, 2009).

Insert Table 1 about here

\section{Factors Related to Patterns of Engagement and Participation}

There has now been a considerable body of research into the factors that are related to different forms of engagement and participation. This research has revealed that engagement and participation are linked to distal macro contextual factors, demographic factors, proximal social factors and endogenous psychological factors. Here, we provide a brief review of some of the principal factors which have been identified to date. 


\section{Macro contextual factors}

Macro contextual factors that have been found to be related to patterns of engagement and participation include: the design of the electoral system; the population characteristics of a country; the structure and design of the political institutions within a country; and the historical, economic and cultural characteristics of a country.

For example, various features of the electoral system are related to the likelihood that people will vote in an election. Voter turnout varies according to whether the electoral system uses proportional representation or a first-past-the-post system (Geys, 2006; Jackman, 1987; Jackman \& Miller, 1995), whether voting is compulsory or optional (Geys, 2006; Jackman, 1987; Smith, 1999; Mattila, 2003), whether voter registration processes are simple or cumbersome (Powell, 1986; Caldeira, Patterson \& Markko, 1985; Highton \& Wolfinger, 1998), whether voting takes place on a rest day or on a working day (Mattila, 2003), and whether multiple elections are held concurrently on the same day or not (Smith, 1999; Geys, 2006). Voter turnout is higher when the electoral system employs proportional representation, compulsory voting, simple registration procedures, voting on a rest day, and concurrent ballots.

Three population features have also been found to be related to voter turnout in elections (Geys, 2006): the size of the population (the larger the electorate, the lower the electoral turnout); population stability (the more stable the population, the higher the level of voting); and the size of the minority share of the total population (the higher the minority share, the lower the voter turnout). This last finding is not a result of minority individuals being less likely to vote than majority individuals, because it has also been found that minority individuals are as likely to vote in elections as majority individuals once demographic differences are controlled (Bobo \& Gilliam, 1990). Instead, the explanation seems to be that as the proportion of minority individuals in a population increases, minority voting also increases while majority voting decreases, thereby reducing voter turnout overall (Oberholzer-Gee \& Waldfogel, 2001).

There is also evidence that the structure and design of political institutions within a country are linked to patterns of participation. For example, the specific forms of participation which are used by citizens have been found to be related to political-institutional design. Thus, citizens living in decentralized polities in which the state is relatively weak in the sense that power is not concentrated in one centre and there are a large number of access points for non-state actors to exert an influence on policy (e.g., Switzerland) display different patterns of participation from citizens living in countries in which state authority is centralized and where there are few opportunities for social movement organizations and other non-state actors to influence policy (e.g., France) (Císař \& Vráblíková, 2012; Kriesi, Koopmans, Duyvendak \& Giugni, 1995). In weak, decentralized states, there are higher levels of more moderate forms of action such as signing petitions and participating in campaigns, while in strong, centralized states there are higher levels of more extreme forms of action such as demonstrations and strikes. A relationship has also been found between the horizontal separation of power within the state (i.e., decentralization) and the overall level of citizen participation: the greater the separation of power, the higher the levels of participation (Vráblíková, 2013).

The historical, economic and cultural characteristics of countries are also all related to patterns of both participation and engagement. For example, citizens in Eastern Europe tend to have lower levels of participation than those in Western Europe; however, in those countries where popular action contributed to the downfall of communist regimes, participation levels are higher (Bernhagen \& Marsh, 2007). Women in more economically developed countries are more politically engaged and participate to a greater extent than those in less well developed countries (Galligan, 2012), and women in countries which have 
predominantly Catholic traditions have lower levels of political interest, political knowledge and political participation than women in countries which have predominantly Protestant traditions (Inglehart \& Norris, 2003).

Finally, there are numerous macro contextual factors which are specifically related to patterns of participation by members of minority and migrant groups. These include whether or not such individuals are granted or denied voting rights, the rules for granting nationality and citizenship to foreign nationals in the country in which they are living, and the extent to which there are formal consultative bodies or channels for liaising with minority and migrant groups and for gathering advice on minority issues, interests and concerns (Ireland, 1994; Martiniello, 2005; Penninx, Martiniello \& Vertovec, 2004). Participation by minority individuals in community organizations and associations is also associated with higher levels of political participation (Fennema \& Tillie, 1999; Putnam, 2000). Perceived discrimination and the context of reception provided by the majority society often function as precipitating factors which stimulate minority and migrant individuals into civic and political engagement and participation (Bedolla, 2000; Portes \& Rumbaut, 2001, 2006; Rumbaut, 2008; Stepick, et al., 2008; Wray-Lake, Syvertsen \& Flanagan, 2008).

\section{Demographic factors}

Various demographic factors, including socioeconomic status (SES), ethnicity, migrant generational status and gender, are also systematically linked to patterns of engagement and participation.

$S E S$, in particular, is a major predictor. For example, individuals with higher SES have higher levels of political and civic knowledge (Delli Carpini \& Keeter, 1996; Hart \& Atkins, 2002; Niemi \& Junn, 1998; Schulz, Ainley, Fraillon, Kerr \& Losito, 2010) and higher levels of civic and political participation (Hart, Atkins \& Ford, 1998; Lopez \& Marcelo, 2008; Zukin et al., 2006). However, it has been argued that what really matters as far as SES is concerned is the correlation between SES and educational attainment, and between SES and the skills that are acquired and exercised in organizations and in jobs, with the latter factors being the more direct determinants of participation (Wolfinger \& Rosenstone, 1980; Verba, et al., 1995).

Ethnicity is also associated with patterns of engagement and participation. For example, ethnic minorities and majorities participate in different kinds of volunteer activities, with the former participating more in activities relating to their own ethnic community and to other minorities (Jensen, 2010; Stepick, et al., 2008). In addition, some minority youth are more likely to discuss news and world events with their parents than majority youth (WrayLake, et al., 2008), although there are also findings suggesting that some minority youth are less likely than majority youth to have political and civic knowledge (Hart \& Atkins, 2002; Torney-Purta, Barber \& Wilkenfeld, 2007). They may also be less likely than majority youth to express their political opinions (e.g., by contacting officials, expressing opinions to the media, and taking part in protests and petitions) (Zukin, et al., 2006).

The generational status of migrant and minority individuals is also linked to patterns of participation (Seif, 2010). For example, the first generation is less likely to be registered to vote than later generations (Stepick, et al., 2008), and is also less participative in terms of actual voting, volunteering and boycotting when compared with majority group individuals (Lopez \& Marcelo, 2008). By contrast, the second generation is often more civically and politically participative than majority group individuals (Lopez \& Marcelo, 2008; Stepick \& Stepick, 2002).

The relationships between ethnicity and political and civic participation are complex, involving multiple interactions between the specific ethnicity of the individual, gender and types and levels of community participation (Bogard \& Sherrod, 2008). Furthermore, it is 
arguable that many of the findings involving ethnicity are due to the reduced opportunities for participation that are linked to lower SES, lower educational attainment and differential religious affiliations, rather than to ethnicity per se (Hart \& Atkins, 2002; Verba, et al., 1995).

Finally, as far as gender is concerned, gender differences have been found in political interest, voter turnout, legal and illegal political action, and participation in voluntary organizations (Galligan, 2012). Education and labour force participation are possible sources of these differences, with men being more likely to be highly educated and to have higher levels of employment than women, which means that they are more likely to acquire the necessary resources and social capital required for participation (Inglehart \& Norris, 2003; Conway, 1999). That said, while men are more likely to have an interest in economic and foreign policy affairs, women are more engaged with social and environmental issues; Galligan (2012) argues that to understand these gendered patterns of participation, it is vital to also take into account the cultural, social and religious norms that determine gender roles within a society, and the differential opportunities to engage that are made available to women and to men.

\section{Social factors}

Turning now to the proximal social factors that are related to civic and political engagement and participation, research has revealed that these are diverse and varied, with the sources of these factors being the family, education, the peer group, the workplace, the mass media, non-political organizations and political institutions.

The family is linked in numerous ways to civic and political engagement and participation. For example: literacy and educational resources in the family home predict levels of civic knowledge (Torney-Purta, Lehmann, Oswald \& Schulz, 2001); adolescents whose parents are interested in political and social issues have higher levels of interest in these issues themselves as well as higher levels of civic knowledge (Schulz, et al., 2010); a family ethic of social responsibility predicts levels of civic commitment (Flanagan, Bowes, Jonsson, Csapo \& Sheblanova, 1998); individuals whose parents engage in civic volunteering have higher levels of civic and political participation, are more attentive to news about politics and government, and are more likely to engage in consumer activism, while individuals who have frequent political discussions with family members are more likely to volunteer and to vote (Zukin, et al., 2006); the best predictor of political partisanship is parental political party preferences (Jennings \& Niemi, 1968; Niemi \& Jennings, 1991); parents who engage in protests are more likely to have offspring who also engage in protests (Jennings, 2002); and parents' levels of political knowledge predict their offsprings' levels of political knowledge, even into the latters' midlife (Jennings, 1996).

A further major source of influences on civic and political engagement and participation is education (Delli Carpini \& Keeter, 1996; Emler \& Frazer, 1999; Nie, Junn \& Stehlik-Barry, 1996; Niemi \& Junn, 1998; Verba, et al., 1995; Zukin, et al., 2006). Some of the links here stem directly from the enhancement of the specific knowledge, skills or motivations which are targeted by the school curriculum. For example, political knowledge can be increased through civics education if an appropriate pedagogical approach is adopted (Niemi \& Junn, 1998), the emphasis which is placed upon elections and voting in school classes is a significant predictor of young people's intentions to vote in the future (TorneyPurta, et al., 2001), and the taking of school classes that generate an interest in politics and national issues predicts the likelihood of discussing the news and watching or listening to national news with parents (Chapman, Nolin \& Kline, 1997).

However, the relationship between education and engagement and participation is much more wide-ranging than just the specific knowledge, skills or motivations targeted by the curriculum; educational effects generalize to a wide range of aspects of engagement and 
participatory behaviours. For example, Zukin, et al. (2006) report that students who attend schools which provide civic training in skills (e.g., in letter writing and debating) are more likely to be involved in organizations outside school, to sign petitions, to participate in boycotts, to follow political news, to engage in charitable fund-raising and to attend community meetings. They also found that students who participate in classroom discussions about volunteering are more likely to volunteer regularly, to work on community problems, to participate in charity fund-raising, and to try and influence other people's voting (see also Feldman, Pasek, Romer \& Jamieson, 2007, and Pasek, Feldman, Romer \& Jamieson, 2008, for similar findings).

Classroom climate also affects a wide range of engagement variables. For example, having an open classroom climate (i.e., the opportunity to discuss controversial social issues and to express and listen to differing opinions in the classroom) predicts young people's levels of civic knowledge and their likelihood of voting in the future (Torney-Purta, et al., 2001), levels of political interest and trust (Hahn, 1998), and the interpretation of political messages and internal efficacy (Azevedo \& Menezes, 2007). Furthermore, perceptions that teachers practise a democratic ethic within the classroom predicts the belief that one lives in a just society and levels of civic commitment (Flanagan, Cumsille, Gill \& Gallay, 2007), transparency of teacher behaviour in the classroom predicts lower levels of political alienation (Gniewosz, Noack \& Buhl, 2009), and participation in discussions within the classroom predicts internal efficacy (Ichilov, 1991).

However, education may actually have its most profound effects not through the enhancement of personal capacities and attitudes towards politics and civic activity. Nie, et al. (1996) argue that it is the effects which education has upon individuals' employment opportunities, social networks and positions of influence in later life that are critical, with these mediating factors being the actual drivers of people's patterns of participation in adult life.

Links have also been found between engagement and participation and the peer group. For example, civic participation is related to having positive relationships with peers (Wentzel \& McNamara, 1999; Yates \& Youniss, 1998), and there is evidence that when youth feel a sense of solidarity with peers at school and believe that most students in their school display institutional pride in the school, they are more likely to commit to civic and political goals and values (Flanagan, et al., 1998). In addition, when youth believe that school, church and college are important in their friends' lives and that they can discuss issues and problems with their friends, they are more likely to participate civically in later life (Zaff, Malanchuk \& Eccles, 2008). However, the amount of time spent in the evenings outside the home with friends is inversely related to civic knowledge in countries where peer group culture devalues education (Torney-Purta, 2002; Torney-Purta, et al., 2001).

Arrangements in the workplace are related to participation as well, with 'spillover' effects to political participation occurring from workplace arrangements that encourage democratic decision-making and the taking of responsibility (e.g., Almond \& Verba, 1963; Greenberg, Grunberg \& Daniel, 1996; Kohn \& Schooler, 1983; Mason, 1982). For example, having the authority to tell others what to do in the workplace and being involved in workplace decision-making predict the likelihood of voting, of being involved in campaigning for a political party or candidate, and of being involved in the affairs of one's local community (Guowei \& Jeffres, 2008; Smith, 1996; Sobel, 1993).

The mass media can impact on engagement and participation. For example, the extent to which individuals attend to news reports on the television and in newspapers is related to levels of political and civic knowledge (Chaffee, Ward \& Tipton, 1970; Hahn, 1998; Linnenbrink \& Anderman, 1995; Torney-Purta, et al., 2001) and the likelihood of voting in the future (Torney-Purta, et al., 2001). In addition, it has been found that people make 
decisions about whether to engage in consumer activism in response to information received from the news media and the Internet (Zukin, et al., 2006). However, the total amount of television which is watched is inversely related to civic activism (Zukin, et al., 2006).

Links have also been found between membership of non-political organizations and civic and political engagement and participation. For example, Hess and Torney (1967) found that membership of peer group organizations was linked to a greater political interest and an enhanced perception of government responsiveness in young people. More recently, it has been found that involvement in formal groups (e.g., religious groups, sports groups, etc.) in which the individual is able to take on active and specific roles is related to prosocial-oriented civic participation (Albanesi, Cicognani \& Zani, 2007), young people who belong to a club or team are much more likely to be involved in community service two years later (Hart, Atkins $\&$ Ford, 1998), people who have high levels of religious attendance and religious activity are more likely to be civically and politically active (Crystal \& DeBell, 2002; Verba, et al., 1995; Youniss, McClellan, Su \& Yates, 1999; Zaff, et al., 2008; Zukin, et al, 2006), and young people who participate in community-based organizations and in extra-curricular activities are more likely to participate both civically and politically in later life (Glanville, 1999; Otto, 1975; Verba, et al., 1995; Youniss, McClellan \& Yates, 1997; Zaff, et al., 2008; Zaff, Moore, Papillo \& Williams, 2003).

Finally, the activities of political institutions themselves are related to levels of participation. For example, being contacted and asked personally to participate in a civic or political process is a powerful predictor of later civic and political participation (Green \& Gerber, 2004; Zukin, et al., 2006). Mobilization by a political institution may be either direct (e.g., via street or doorstep campaigning, phone calls, mail shots, advertising, etc.) or indirect (where other people within an individual's social networks mobilize them into action) (Rosenstone \& Hansen, 2003). Indirect mobilizing channels may be as effective as direct ones, especially when individuals live in decentralized states with a high number of independent veto points or power centres (Vráblíková, 2013).

\section{Integrating existing findings on macro contextual, demographic and social factors}

The findings which have been reviewed so far are numerous and diverse, and it will be helpful to summarize these findings at this juncture. A diagrammatic summary is provided in Figure 1. This diagram shows the causal pathways through which macro contextual, demographic and social factors can impact on political and civic engagement and participation.

\section{Insert Figure 1 about here}

Macro contextual factors are shown on the left-hand side of the diagram, and are categorized into two main types: (i) the specific characteristics of the electoral, political and legal institutions and processes in the country in which an individual lives; and (ii) the broader characteristics of the country, including the historical, economic, cultural and population characteristics of the country.

The demographic and social factors are shown in the centre of the diagram. It is clear from the preceding review that the beliefs, attitudes, values, norms, discourses and practices of many different social actors can influence an individual's patterns of engagement and participation. Family discourses and practices play a particularly crucial role here, not only through their direct impact on the individual but also indirectly through, for example, parents' educational choices (which in turn influence the educational curriculum, teachers and peer group to which their children are exposed) and through the purchase and use of TV, books, newspapers, information and communications technology (ICT) and other media resources 
(which influences the media contents to which family members are exposed). Family discourses and practices themselves are, of course, heavily constrained and influenced by family SES, family ethnicity and migrant generational status.

Psychological factors are shown in an abbreviated format on the right-hand side of the diagram. These factors are discussed more explicitly in the following section of this article.

The causal pathways through which macro contextual, demographic and social factors influence an individual's patterns of engagement and participation are represented by the arrows in Figure 1. The two sets of macro factors mutually influence each other (institutional structures and processes influence the historical, economic, cultural and population characteristics of countries, while these characteristics in turn influence institutional design and processes), and so there are bidirectional arrows between them. There are also bidirectional influences between both sets of macro factors and the beliefs, attitudes, values, norms, discourses and practices of societal members (macro factors provide the setting against which individuals position themselves ideologically, politically and socially, but individuals are also able to change the macro setting through their own political and civic actions).

Figure 1 summarizes how all of the following social factors can impact on an individual's political and civic engagement and participation: family discourses and practices; educational curricula and textbooks; teachers' discourses and practices; workplace discourses and practices; discourses and practices of peer groups and social networks beyond the family and the workplace; other social experiences outside the family, the school, the workplace and social networks; personal contact and involvement with political and non-political institutions and organizations; and representations of institutions, organizations and political and civic events in the mass media.

However, it is important to emphasize that these are all only potential sources of influence. Individuals do not passively absorb influences from their social environment. Instead, they are agentic social actors who actively select information from their environments, resist or ignore information which is irrelevant to their own needs, motivations and goals, and construct their own beliefs and attitudes from the environmental information to which they have access (Bandura, 1986). In other words, endogenous perceptual, attentional, cognitive, motivational and affective processes filter environmental influences and also contribute to the shaping of the political and civic beliefs and attitudes which an individual constructs.

In addition, individuals themselves have effects on how other people in their environment behave towards them. Individuals engage in interactions in many different social contexts, and the causality which takes place within these contexts is often inherently bidirectional (Kiousis, McDevitt \& Wu, 2005; McDevitt, 2006; Schaffer, 1996). Furthermore, where individuals rise to positions of power or influence within society, their discourses and actions can also impact on the macro characteristics of the society. The impact of the individual on the various social and macro contextual factors is depicted in Figure 1 by the arrows emanating from the individual's discourses and actions that flow from right to left in the diagram.

The balance of influence between the different factors varies from one societal setting to another, depending on the particular constellation of macro and social factors which is present. For this reason, different factors may be the primary drivers of political and civic engagement and participation in different demographic groups and in different settings, with the relative weightings assigned to the various arrows in Figure 1 varying from one societal setting to another and from one demographic group to another. This diagram therefore captures the variability which occurs across and within populations in the macro, demographic and social factors that drive political and civic participation. 
A more extended discussion of the model shown in Figure 1 is presented in Barrett (in press), which interested readers should consult for further details.

\section{Psychological factors}

In addition to the factors that have been discussed above, there are also many endogenous psychological factors that have been found to impact on civic and political participation. These factors together and cumulatively comprise what we have termed political and civic 'engagement' in this article.

First, a wide range of cognitive factors such as political and civic knowledge, beliefs, attitudes, opinions and social and cultural values are linked to patterns of participation (Caprara, Schwartz, Capanna, Vecchione \& Barbaranelli, 2006; Torney-Purta \& Amadeo, 2003; Zukin, et al., 2006). For example, Zukin, et al. (2006) found that the most consistent predictor of all forms of participation was a factor which they termed 'political capital', which represents the total set of political resources that an individual has at the psychological level and includes political knowledge, the amount of attention paid to political issues, internal efficacy and a sense of civic duty.

Other important cognitive factors that have been linked to participation are social trust (i.e., the belief that other people will generally behave in ways that are beneficial rather than detrimental to oneself), institutional trust (i.e., the belief that societal and political institutions will generally operate in ways that are beneficial rather than detrimental to people) and beliefs about good citizenship (Dalton, 2008; Norris, 1999; Putnam, 2000; Theiss-Morse, 1993). For example, Torney-Purta, Barber and Richardson (2004; see also Torney-Purta, Richardson \& Barber, 2004) found that institutional trust predicted voting, volunteering, joining a political party, and writing letters to a newspaper about social or political concerns, while Theiss-Morse (1993) found that beliefs about good citizenship predicted voting, contacting government officials, other forms of conventional participation (e.g., persuading others how to vote), and non-conventional participation (e.g., joining public demonstrations).

Three specific cognitive factors that have been found to be particularly important are internal, external and collective efficacy (Craig, Niemi \& Silver, 1990; Klandermans, 1997; Pasek, et al., 2008; van Zomeren, Postmes \& Spears, 2008). Internal efficacy (i.e., the belief that one understands civic and political affairs and has the competence to participate in civic and political events) is one of the most significant psychological predictors of participation, and it forms part of the cluster of beliefs that make up political capital (Zukin, et al., 2006). External efficacy (i.e., the belief that public and political officials and institutions are responsive to citizens' needs, actions, requests and demands) also predicts participation. For example, half of the decline in electoral turnout in American presidential elections between 1960 and 1980 is attributable to the decline in external efficacy which took place across this period (Abramson \& Aldrich, 1982). Both internal and external efficacy are related to political interest (Craig, et al., 1990; Schulz, 2005) and to institutional trust (Acock \& Clarke, 1990). However, they have different patterns of relationships to other variables. For example, internal efficacy but not external efficacy is related to political knowledge (Delli Carpini \& Keeter, 1996) and relationships between internal efficacy and participation are stronger and more consistent than relationships between external efficacy and participation (Craig, et al., 1990; Harris, 1999; Shingles, 1981). Collective efficacy (i.e., the belief that the problems of a group can be solved through collective activity) has been found to be especially important as a predictor of collective action (e.g., participating in protests and demonstrations), and is itself predicted by identification with the group and by the perception of social support for collective action within the group (Klandermans, 2002; van Zomeren, et al., 2008; van Zomeren, Spears, Fischer \& Leach, 2004). 
Emotional factors are also related to civic and political participation. Both negative emotions (e.g., anger towards a perceived social injustice, feelings of discrimination, dissatisfaction with the status quo and the desire to contribute to social change) and positive emotions (e.g., satisfaction with past participation experiences, institutional pride, and institutional trust) have been found to play a role (Flanagan, et al., 1998; Leach, Iyer \& Pedersen, 2006; van Zomeren, et al., 2004). For example, van Zomeren, et al. (2004) found that levels of anger about a social or political issue directly predicts the likelihood of taking part in demonstrations and other forms of collective protest over that issue.

As noted already, social identifications, which involve experiencing a sense of belonging to a social group (such as a community, a social or political movement, an ethnic group, a national group, etc.), are linked to levels of participation (Deaux, Reid, Martin \& Bikmen, 2006; Simon, et al., 1998; van Zomeren, et al., 2008). Social identifications entail adopting group norms concerning participation, and they can also provide ingroup models for participatory behaviours and a sense of social support for one's opinions and actions. A somewhat broader psychological concept is that of sense of community, which consists of a number of psychological dimensions, including a feeling of being a part of a territorial or relational community, a feeling that one has opportunities for participation and influence within the community, a feeling that one's needs are being satisfied by the community, and a feeling of a shared emotional connection with other people within the community (McMillan \& Chavis, 1986). A high sense of community predicts high levels of both political and civic participation (Cicognani \& Zani, 2009).

Personal motivations and goals are also important. Motivations have been investigated most extensively in relationship to volunteering and civic participation (Omoto \& Snyder, 1995, 2002), where it has been found that individuals have diverse motivations for participating in voluntary activities. These include: in order to express personal values; to acquire further knowledge and understanding; to gain experience and to develop personally; from a sense of community concern; and to enhance one's own self-esteem. The stronger these motivations are, the longer an individual engages in voluntary service (Omoto \& Snyder, 1995).

\section{Integrating existing findings on the psychological factors that comprise engagement}

These numerous psychological factors interact with one another in complex ways. Individual psychological factors sometimes moderate or amplify the effects of other factors, and sometimes their effects on participation are mediated by other psychological factors rather than being direct. Explicit path models revealing the patterns of causality which operate between subsets of these psychological factors have been proposed by numerous researchers (e.g., Klandermans, 2002; Nie, et al., 1996; Omoto \& Snyder, 1995; Pasek, et al., 2008; van Zomeren, et al., 2008; van Zomeren, et al., 2004). These path models have focused primarily on the psychological engagement factors which predict three specific types of participation, namely collective action (e.g., participating in demonstrations), voting and volunteering.

Interestingly, the individual path models which have been proposed can be connected together into a single much larger integrative model of the psychological factors comprising political and civic engagement, with no inconsistencies arising (Barrett, in press). This larger integrative model is shown in Figure 2, where single-headed arrows depict predictive relationships that have been identified through regression analyses or structural equation modelling, and double-headed arrows depict relationships that have been identified using correlations. 
It is noteworthy that the model depicted in Figure 2 represents a single integrated causal psychological model of participation, with shared psychological factors across collective action, voting and volunteering (in particular internal efficacy). This model provides a detailed specification of the perceptual, attentional, cognitive, affective and motivational drivers of these three types of participation. It can therefore be viewed as an unpacking of these psychological components that are contained in the macro-demographicsocial model shown in Figure 1. As such, this second model locks directly onto the previous model.

Connecting the two models together in this way produces a comprehensive integrative model of collective action, voting and volunteering (which represent distinctive forms of nonconventional political, conventional political and civic participation, respectively) which covers all four levels of factors: macro, demographic, social and psychological. The qualifications which were previously made in connection with Figure 1 also apply to this second model: that is, the factors and causal pathways which are shown in this model only denote possible factors and pathways. In practice, different subsets of factors and pathways will be the primary drivers of political and civic participation among different demographic subgroups and in different macro settings.

For further discussion of the model shown in Figure 2, interested readers should consult Barrett (in press).

\section{A Summary of Some Findings Which Emerged from the Secondary Analysis of Existing Datasets in the PIDOP Project}

\section{Rationale}

We now turn to the second aim of this article, which is to provide a summary of some of the findings which emerged from the secondary analysis of existing datasets in the PIDOP project. One way in which multiple levels of factors (such as those shown in Figures 1 and 2) can be explored simultaneously is through secondary analysis. There are many international survey datasets which can be exploited for this purpose. One of the primary advantages of using the data from these surveys is the large sample sizes available, which permits powerful statistical modelling to be performed. A second advantage is that such surveys usually collect data from nationally representative samples, which boosts confidence in the results of the analyses.

The PIDOP project therefore undertook analyses of the data from several existing surveys (in addition to collecting new data in the nine participating countries). The overall aim of these secondary analyses was to identify empirically the factors which drive civic and political participation in different countries. There were two main sub-goals here: first, to describe patterns of civic and political participation across different countries and across key demographic groupings; and second, to identify the underlying factors which are related to variations in the patterns of civic and political participation both across and within countries.

In order to achieve these goals, the project drew together data from a number of international surveys that contain questions relating to participation. These were: the European Social Survey, Eurobarometer, the International Social Survey Programme, the Comparative Study of Electoral Systems, and the World Values Survey. In addition, indices of macro contextual factors for different countries were taken from two sources, the Country Indicators for Foreign Policy (CIFP, 2011) and the Economist Intelligence Unit (Kekic, 2007). 
A range of analyses was conducted on these datasets. These included: basic descriptive statistics; structural equation models examining the psychological and demographic predictors of participation; multilevel models linking these micro processes to broader macro contextual factors; and latent class analysis to identify distinct 'classes' of political participation. Because the datasets do not include much information on the proximal social factors that are linked to participation, this level of factors was not included in these secondary analyses (but were instead addressed in the PIDOP project through the collection of new data in the participating countries).

Four distinct types of participation were examined in these analyses: voting; other forms of conventional political participation (e.g., belonging to a political party, running for political election, working on political election campaigns for candidates or parties, giving donations to political parties, trying to persuade others to vote); non-conventional political participation (e.g., participating in protests, demonstrations and marches, signing petitions, writing letters or emails to politicians or public officials, writing articles or blogs with a political content for the media, participating in fundraising events for a political cause); and civic participation (e.g., belonging to community organizations and other non-political organizations such as religious institutions, sports clubs, etc.).

\section{A Summary of the Principal Findings}

The descriptive analyses revealed that there was a great deal of variability in all four forms of participation, both within and across countries. However, some clear demographic consistencies across countries were also uncovered. For example: younger people aged under 25 and ethnic minority individuals were less likely to vote in all countries; younger people were also less likely to be involved in conventional activities in all countries; and males were more likely to be involved in conventional forms of participation in all countries. In addition, in some but not all countries, younger people and ethnic minority individuals were more likely to be involved in non-conventional forms of political activity. As far as civic participation was concerned, there were also differences between countries, but there was comparatively less demographic variability within countries.

Analysis of Eurobarometer data collected since 1973 revealed consistently high intentions to vote each year (always above $80 \%$ of the sample). This was noticeably higher than the self-reported voting behaviour of individuals. It was also considerably higher than the actual levels of voter turnout in each country (which in some countries are as low as $50 \%$ ). This demonstrates a disconnection between expressed voting intentions and actual behaviour.

Structural equation modelling was used to explore the relationships between psychological factors (i.e., engagement) and the four types of participation. These analyses were conducted on the data from the initial round of the European Social Survey which fielded a series of questions covering 'Citizenship, Involvement and Democracy'. Several psychological factors were investigated in these analyses, including:

- Attentiveness to political issues and affairs, for example, on television, on the radio, and in newspapers

- Interest in politics

- Internal efficacy

- External efficacy

- Institutional trust 
- Social capital - how much one trusts other people in general, and how often one meets with friends, relatives or colleagues

- Ideological identity - whether one holds an extreme position on either the right or the left of the political spectrum or whether one holds a more moderate centrist position

- Opinionation - holding opinions about civic and political matters

- Perceived discrimination - the perception that one is discriminated against because of the group to which one belongs

A high degree of variability was found both across and within countries in these psychological factors. For example, levels of attentiveness and political interest vary widely across countries, from $20 \%$ of the population through to $65 \%$ depending on the country. However, some consistent patterns were overlaid on this variability. For example, attention to political broadcasts on television was always higher than attention to politics via other media sources, and there were lower levels of trust in politicians than in any other institution across all countries.

Consistent with the pathways shown in Figure 2, it was also found that people who had high levels of interest in politics and high levels of internal efficacy showed high levels of all four types of participation (i.e., voting, other forms of conventional political participation, non-conventional political participation and civic participation). Such people were also more likely to hold opinions, with this high level of opinionation further increasing both their involvement in non-conventional political activities and their levels of civic participation. Opinionation has not previously been included in the psychological path models. Our findings suggest that it needs to be added to the model in Figure 2. In addition to being robust predictors of participation, political interest and internal efficacy were highly correlated with each other, so much so that in the statistical analyses their independent effects could not be isolated.

It was also found that perceived discrimination (an index of identity threat: see Figure 2) had different effects on different types of participation. For example, individuals who felt that they were discriminated against because of the group to which they belonged were less likely to vote, but were more likely to participate through other forms of conventional participation, non-conventional means and civic means. The link between identity threat and collective action (a sub-type of non-conventional political participation) is already represented in Figure 2 (mediated by group-based anger), but our findings suggest that identity threat also needs to be linked in the diagram to voting (negatively) and to volunteering (positively). It is a question for future research to address whether these links to voting and volunteering are similarly mediated by group-based anger or by other factors.

In addition, we found that high attentiveness to politics was linked to a greater tendency to vote and to participate civically, while high external efficacy increased the tendency to be involved in conventional and non-conventional activities, but showed no direct influence on voting behaviour. We also found that institutional trust was linked to a higher tendency to vote. All of these findings are consistent with Figure 2.

However, there were also some findings which were not consistent with the model shown in Figure 2. For example, while political attentiveness was indeed linked to both voting and civic participation (consistent with the model), political attentiveness was also negatively related to non-conventional political participation (inconsistent with the model, if collective action is viewed as a form of non-conventional participation). Further investigation is clearly required to elucidate the role of political attentiveness.

Multi-level modelling was used to examine the role of macro contextual factors. The main findings that were obtained are summarized in Table 2. The top rows in this table (labelled COUNTRY EFFECT) show the magnitude of country differences in each of the 
four forms of participation as revealed through the analysis of data from the European Social Survey (ESS), the International Social Survey Programme (ISSP) and the World Values Survey (WVS). Significant differences between countries were found in all four forms of participation. The between-country differences were largest for civic participation (where $26 \%$ of the total variability in the ISSP, and $25 \%$ in the ESS, was due to between-country differences) and smallest for conventional participation (11\% and 3\% respectively).

Insert Table 2 about here

The central rows in Table 2 (labelled MACRO) show that, with the exception of voting, these between-country differences can be partially explained by differences in the macro contextual factors that characterize each country. A + in the table shows that there was a statistically significant positive relationship between the macro factor and the form of participation, while NS shows that there was no significant relationship (N.B. no negative relationships were found). As can be seen, conventional political, non-conventional political and civic participation were all positively related to macro factors. The strongest effects were associated with government efficiency, government accountability and the country's record in relation to the rule of law (inclusion of these measures in the model accounted for well over half of the differences between countries). Participation levels were found to be higher in countries that were identified as performing well on these measures. The other macro factors were also linked to participation rates but were generally associated with smaller reductions in the variations attributable to between-country differences.

The lower rows in Table 2 (labelled MACRO $\rightarrow$ MICRO) summarize how differences in participation within countries are related to the macro characteristics of those countries. These rows show that the magnitude of differences in participation levels based on gender, levels of political interest and internal efficacy (the latter two of which are strongly correlated with one another), and to a lesser extent age and social trust, are partially shaped by the macro factors characterizing the country in which the individuals are living. For example, in countries that are higher on government efficiency, the gender difference in levels of conventional and non-conventional participation is larger than average (represented by Gender[+] in the table); in countries that are lower on government efficiency, the gender gap in these forms of participation is smaller than average. The magnitude of gender differences in conventional and non-conventional forms of participation is also linked to government accountability and having a good record on the rule of law. In contrast, differences in conventional and non-conventional participation based on political interest and internal efficacy are reduced in countries which are high on government efficiency, government accountability and a good record on the rule of law (represented by Interest and efficacy[-] in the table). The analyses also revealed that the positive role of social trust in generating civic participation is marginally more pronounced in countries which are high on all six macro factors.

Finally, latent class analysis was used to discover whether citizens can be grouped into different classes based on their patterns of participation. The analysis uncovered four distinct classes of people based on their overall pattern of participation:

- Those who are both politically and civically active - These individuals participate in all four ways to a high extent, and are more likely to be older, male, and not from an ethnic minority group.

- Those who are inactive both politically and civically - These individuals have a very low tendency to participate in all four ways, and are more likely to be younger and 
from ethnic minority groups, and are less likely to be male than those in the politically active group.

- Those who have high levels of both non-conventional and civic activity - These individuals are involved in non-conventional political activity and are civically engaged, but are less likely to vote or to be involved in conventional political activities. Compared to the politically and civically active group, this group is more likely to be young. Ethnic minority individuals are more likely to be in this third category than in the first category, but they are even more likely to be in the second, inactive, category above.

- Voting-only - These individuals are similar in demographic make-up to the politically and civically active group, but members are more likely to be female.

In summary, the analyses revealed that participation is indeed related to macro institutional factors, demographic factors and psychological factors. There were significant variations between countries in the magnitude of some of the psychological drivers of participation, as well as differences within countries based on demographics. Importantly, the multilevel modelling revealed that the way that demographic factors (such as gender and age) and psychological factors (such as political interest, internal efficacy and social trust) relate to forms of participation other than voting is influenced by macro factors (especially government efficiency, government accountability and the rule of law).

The existence of these complex patterns demonstrates the need for theoretical explanations to encompass macro, demographic and psychological drivers of political and civic participation. The findings also demonstrate the need for theoretical explanations to address the specificities of particular types of participation (voting, other forms of conventional political participation, non-conventional political participation and civic participation) among particular demographic subgroups living within particular national contexts. Thus, the outcomes of these analyses underline the need for integrative multi-level theories of participation, rather than theories that focus on only a single level of factors.

Readers wishing to find out more about the details of the secondary analyses which were conducted under the PIDOP project, and the findings that were obtained, should consult Brunton-Smith (2011), which provides a full technical report of all the analyses that have been summarized in this section.

\section{Conclusion}

It is clear from the previous research reviewed in the first part of this article and from the secondary analyses reported in the second part that civic and political participation are influenced by multiple levels of factors, including distal macro contextual factors, demographic factors, proximal social factors ${ }^{3}$ and endogenous psychological factors (i.e., psychological engagement). In addition, it is clear that the factors that operate at these different levels interact in complex ways in driving citizens' patterns of participation.

Two psychological factors which were identified as having a consistent effect on all four types of participation (i.e., voting, other forms of conventional political participation, non-conventional participation, and civic participation) were political interest and internal efficacy. This finding suggests that psychological interventions aimed at increasing levels of participation should focus primarily on amplifying the political interest and internal efficacy of the individuals that are being targeted. For example, in the case of youth, the programmes that are adopted by schools or youth centres should aim at encouraging young people in developing an interest in political and civic affairs, fostering their knowledge and 
understanding of political and civic matters, and supporting their acquisition of the personal skills which they require in order to participate effectively in the political and civic life of their community and country.

However, the finding that factors at different levels interact in driving patterns of participation implies that policies or interventions targeting psychological factors other than political interest and internal efficacy may have to be tailored specifically to particular demographic subgroups living within particular national contexts. In other words, different policies or forms of intervention may be required in different national contexts and for enhancing participation among younger vs. older individuals, women vs. men, and minority vs. majority individuals. ${ }^{4}$

The findings from the PIDOP project also present a challenge for social scientists' attempts to explain the nature and causes of political and civic participation in theoretical terms. As factors at all four levels clearly do have an influence on participatory behaviours, theoretical explanations that fail to incorporate all four levels in their formulations will inevitably be only partial. Similarly, theories which fail to take into account that factors at different levels interact to drive citizens' patterns of participation will likewise be limited in their explanatory power. Instead, integrative multi-level theories which take into account the specific psychological characteristics and social circumstances of particular demographic subgroups living within particular national contexts (such as the one that has been presented across Figures 1 and 2 in this article) are required. The further elaboration of such theories is likely to require substantial collaboration between political scientists, sociologists and psychologists.

\section{References}

Abramson, P. R. \& Aldrich, J. H. (1982) The decline of electoral participation in America, American Political Science Review, 76(3), pp. 502-521.

Acock, A. C. \& Clarke, H. D. (1990) Alternative measures of political efficacy: Models and means, Quality and Quantity, 24(1), pp. 87-105.

Albanesi, C., Cicognani, E. \& Zani, B. (2007) Sense of community, civic engagement and social well-being in Italian adolescents, Journal of Community and Applied Social Psychology, 17(5), pp. 387-406.

Almond, G. \& Verba, S. (1963) The Civic Culture: Political Attitudes and Democracy in Five Nations (Princeton, NJ: Princeton University Press).

Azevedo, C. N. \& Menezes, I. (2007) Learning politics beyond cognition: The role of experience and participation in political development, in: N. Kryger \& B. Ravn (Eds), Learning beyond Cognition, pp. 95-114 (Copenhagen: Danish University of Education).

Bandura, A. (1986) Social Foundations of Thought and Action (Englewood Cliffs, NJ: Prentice-Hall).

Barrett, M. (in press) An integrative model of political and civic participation: Linking the macro, social and psychological levels of explanation, in: M. Barrett \& B. Zani (Eds), Political and Civic Engagement: Multidisciplinary Perspectives (London: Routledge).

Bedolla, L.G. (2000) They and we: Identity, gender and politics among Latino youth in Los Angeles, Social Science Quarterly, 81(1), pp. 106-122.

Bernhagen, P. \& Marsh, M. (2007) Voting and protesting: explaining citizen participation in old and new European democracies, Democratization, 14(1), pp. 44-72.

Bobo, L. \& Gilliam, F. D. (1990) Race, sociopolitical participation and black empowerment, American Political Science Review, 84(1), pp. 377-393. 
Bogard, K. L. \& Sherrod, L. R. (2008) Citizenship attitudes and allegiances in diverse youth, Cultural Diversity and Ethnic Minority Psychology, 14(4), pp. 286-296.

Brunton-Smith, I. (2011) Modelling existing survey data: Full technical report of PIDOP Work Package 5. Department of Sociology, University of Surrey. Available at http://epubs.surrey.ac.uk/739988/ (accessed 29 June 2012).

Caldeira, G. A., Patterson, S. C. \& Markko, G. A. (1985) The mobilisation of voters in congressional elections, Journal of Politics, 48(2), pp. 490-509.

Caprara, G. V., Schwartz, S., Capanna, C., Vecchione, M., \& Barbaranelli, C. (2006) Personality and politics: Values, trait and political choice, Political Psychology, 28(5), pp. 609-632.

Chaffee, S. H., Ward, L. S. \& Tipton, L. P. (1970) Mass communication and political socialization, Journalism Quarterly, 47(4), pp. 447-459.

Chapman, C., Nolin, M . J. \& Kline, K. (1997) Student Interest in National News and its Relation to School Courses (NCES 97-970) (Washington, DC: National Center for Education Statistics).

Cicognani, E. \& Zani, B. (2009) Sense of community and social participation among adolescents and young adults living in Italy, in: D. Dolejšiová \& M. A. Garcia López (Eds), European Citizenship - In the Process of Construction: Challenges for Citizenship, Citizenship Education and Democratic Practice in Europe, pp. 100-113 (Strasbourg: Council of Europe Publishing).

CIFP (2011) Country Indicators for Foreign Policy: Governance and Democracy Processes. (Ottowa, Canada: Carleton University).

Císař, O. \& Vráblíková, K. (2012) Contextual determinants of political participation. Unpublished paper, Work Package 3, The PIDOP Project.

Conway, M. M. (1999) Political Participation in the United States (3rd edition) (Washington: CQ Press).

Craig, S. C., Niemi, R. G. \& Silver, G. E. (1990) Political efficacy and trust: A report on the NES pilot study items, Political Behaviour, 12(3), pp. 289-314.

Crystal, D. S. \& DeBell, M. (2002) Sources of civic orientation among American youth: Trust, religious valuation, and attributions of responsibility, Political Psychology, 23(1), pp. 113-132.

Dalton, R. J. (2008) The Good Citizen: How a Younger Generation is Reshaping American Politics (Washington, DC: CQ Press).

Deaux, K., Reid, A., Martin, D. \& Bikmen, N. (2006) Ideologies of diversity and inequality: Predicting collective action in groups varying in ethnicity and immigrant status, Political Psychology, 27(1), pp. 123-146.

Delli Carpini, M. \& Keeter, S. (1996) What Americans Know about Politics and Why it Matters (New Haven, CT: Yale University Press).

Emler, N. \& Frazer, E. (1999) Politics: The education effect. Oxford Review of Education, 25(1-2), pp. 251-274.

Feldman, L., Pasek, J., Romer, D., \& Jamieson, K. H. (2007) Identifying best practices in civic education: Lessons from the Student Voices program, American Journal of Education, 114(1), pp. 75-100.

Fennema, M. \& Tillie, J. (1999) Political participation and political trust in Amsterdam: civic communities and ethnic networks, Journal of Ethnic and Migration Studies, 25(4), pp. 703-726.

Flanagan, C. A., Bowes, J. M., Jonsson, B., Csapo, B., \& Sheblanova, E. (1998) Ties that bind: Correlates of adolescents' civic commitments in seven countries, Journal of Social Issues, 54(3), pp. 457-475. 
Flanagan, C., Cumsille, P., Gill, S., \& Gallay, L. (2007) School and community climates and civic commitments: Patterns for ethnic minority and majority students, Journal of Educational Psychology, 99(2), pp. 421-431.

Galligan, Y. (2012) The contextual and individual determinants of women's civic engagement and political participation. Unpublished paper, Work Package 3, The PIDOP Project.

Geys, B. (2006) Explaining voter turnout: a review of aggregate-level research, Electoral Studies, 25(4), pp. 637-663.

Glanville, J. L. (1999) Political socialization or selection? Adolescent extracurricular participation and political activity in early adulthood, Social Science Quarterly, 80(2), pp. 279-290.

Gniewosz, B., Noack, P. \& Buhl, M. (2009) Political alienation in adolescence: Associations with parental role models, parenting styles and classroom climate, International Journal of Behavioral Development, 33(4), pp. 337-346.

Green, D. P. \& Gerber, A. S. (2004) Get Out the Vote! How to Increase Voter Turnout (Washington, D.C.: Brookings Institution Press).

Greenberg, E. S., Grunberg, L. \& Daniel, K. (1996) Industrial work and political participation: beyond 'simple spillover', Political Research Quarterly, 49(2), pp. 305330.

Guowei, J. \& Jeffres, L. (2008) Spanning the boundaries of work: workplace participation, political efficacy, and political involvement, Communication Studies, 59(1), pp. 3550.

Hahn, C. (1998) Becoming Political: Comparative Perspectives on Citizenship Education (Albany: State University of New York Press).

Harris, F. C. (1999) Will the circle be unbroken? The erosion and transformation of AfricanAmerican civic life, in: R. Fullinwider (Ed), Civil Society, Democracy and Civic Renewal, pp. 317-338 (New York: Roman and Littlefield).

Hart, D., \& Atkins, R. (2002) Civic development in urban youth, Applied Developmental Science, 6(4), pp. 227-236.

Hart, D., Atkins, R., \& Ford, D. (1998) Urban America as a context for the development of moral identity in adolescence, Journal of Social Issues, 54(3), pp. 513-530.

Hess, R. D., \& Torney, J. V. (1967) The Development of Political Attitudes in Children (Chicago: Aldine).

Highton, B. \& Wolfinger, R. E. (1998) Estimating the effects of the National Voter Registration Act of 1993, Political Behavior, 20(2), pp. 79-104.

Ichilov, O. (1991) Political socialization and schooling effects among Israeli adolescents, Comparative Education Review, 35(3), pp. 430-447.

Inglehart R. \& Norris, P. (2003) Rising Tide: Gender Equality and Cultural Change Around the World (Cambridge: Cambridge University Press).

Ireland, P. (1994) The Policy Challenge of Ethnic Diversity (Cambridge, MA: Harvard University Press).

Jackman, R. W. (1987) Political institutions and voter turnout in the industrial democracies. American Political Science Review, 81(2), pp. 405-423.

Jackman, R..\& Miller, R. A. (1995) Voter turnout in the industrial democracies during the 1980s. Comparative Political Studies, 27(4), pp. 467-492.

Jennings, M. K. (1996) Political knowledge over time and across generations, Political Opinion Quarterly, 60(2), pp. 228-252.

Jennings, M. K. (2002) Generation units and the student protest movement in the United States: An intra- and intergenerational analysis, Political Psychology, 23(2), pp. 303324. 
Jennings, M. K. \& Niemi, R. G. (1968) The transmission of political values from parent to child. American Political Science Review, 62(2), pp. 169-184.

Jensen, L. A. (2010) Immigrant youth in the United States: coming of age in diverse cultures, in: L. R. Sherrod, J. Torney-Purta \& C. A. Flanagan (Eds), Handbook of Research on Civic Engagement in Youth, pp. 425-443 (Hoboken, N.J.: John Wiley \& Sons).

Kekic, L. (2007) The Economist Intelligence Unit's index of democracy. The World in 2007 (London: The Economist).

Kiousis, S., McDevitt, M., \& Wu, X. (2005) The genesis of civic awareness: Agenda-setting in political socialization, Journal of Communication, 55(4), pp. 756-774.

Klandermans, B. (1997) The Social Psychology of Protest (Oxford: Blackwell).

Klandermans, B. (2002) How group identity helps to overcome the dilemma of collective action. American Behavioral Scientist, 45(5), pp. 887-900.

Kohn, M. \& Schooler, C. (1983) Work and Personality: An Inquiry into the Impact of Social Stratification (Norwood, NJ: Ablex).

Kriesi, H., Koopmans, R., Duyvendak, J.W. \& Giugni, M.G. (1995) New Social Movements in Western Europe: A Comparative Analysis (London: UCL Press).

Leach, C. W., Iyer, A. \& Pedersen, A. (2006) Anger and guilt about ingroup advantage explain the willingness for political action, Personality and Social Psychology Bulletin, 32(9), pp. 1232-1245.

Linnenbrink, L. \& Anderman, E.M. (1995) Motivation and news-seeking behaviour. Paper presented at the Annual Meeting of the American Educational Research Association, San Francisco, CA, April 18-22.

Lopez, M. H. \& Marcelo, K. B. (2008) The civic engagement of immigrant youth: New evidence from the 2006 Civic and Political Health of the Nation Survey, Applied Developmental Science, 12(2), pp. 66-73.

Martiniello, M. (2005) Political participation, mobilisation and representation of immigrants and their offspring in Europe. Willy Brandt Series of Working Papers in International Migration and Ethnic Relations, 1/05 (Malmö, Sweden: Malmö University).

Mason, R. (1982) Participatory and Workplace Democracy (Carbondale, IL: Southern Illinois University Press).

Mattila, M. (2003) Why bother? Determinants of turnout in the European elections, Electoral Studies, 22(3), pp. 449-468.

McDevitt, M. (2006) The partisan child: Developmental provocation as a model of political socialization, International Journal of Public Opinion Research, 18(1), pp. 67-88.

McMillan, W. D. \& Chavis, M. D. (1986) Sense of community: A definition and a theory, Journal of Community Psychology, 14(1), pp. 6-23.

Nie, N. H., Junn, J. \& Stehlik-Barry, K. (1996) Education and Democratic Citizenship in America (Chicago: University of Chicago Press).

Niemi, R. G. \& Jennings, M. K. (1991) Issues and inheritance in the formation of party identification, American Journal of Political Science, 35(4), pp. 970-988.

Niemi, R. \& Junn, J. (1998) Civic Education: What Makes Students Learn? (New Haven: Yale University Press).

Norris, P. (Ed) (1999) Critical Citizens: Global Support for Democratic Governance (Oxford: Oxford University Press).

Oberholzer-Gee, F. \& Waldfogel, J. (2001) Electoral acceleration: the effect of minority population on minority voter turnout. NBER Working Paper 8252 (Cambridge MA: National Bureau of Economic Research).

Omoto, A. M. \& Snyder, M.(1995) Sustained helping without obligation: Motivation, longevity of service, and perceived attitude change among AIDS volunteers, Journal of Personality and Social Psychology, 68(4), pp. 671-686. 
Omoto A. M. \& Snyder M. (2002) Considerations of community: the context and process of volunteerism, American Behavioral Scientist, 45(5), pp. 846-867.

Otto, L. B. (1975) Extracurricular activities in the educational attainment process, Rural Sociology, 40(2), pp. 162-176.

Pasek, J., Feldman, L., Romer, D. \& Jamieson, K. H. (2008) Schools as incubators of democratic participation: Building long-term political efficacy with civic education, Applied Developmental Science, 12(1), pp. 26-37.

Penninx, R., Martiniello, M. \& Vertovec, S. (Eds) (2004) Citizenship in European Cities: Immigrants, Local Politics and Integration Policies (London: Ashgate).

Portes, A. \& Rumbaut, R.G. (2001) Legacies: The Story of the Immigrant Second Generation (Berkeley: University of California Press).

Portes, A. \& Rumbaut, R. G. (2006) Immigrant America: A Portrait (3rd edition) (Berkeley: University of California Press).

Powell, G. B. (1986) American voter turnout in comparative perspective, American Political Science Review, 80(1), pp. 17-43.

Putnam, R. D. (2000) Bowling Alone: The Collapse and Revival of American Community (New York: Simon \& Schuster).

Rosenstone, S. J. \& Hansen, J. M. (2003) Mobilization, Participation, and Democracy in America (New York: Longman).

Rumbaut, R. G. (2008) Reaping what you sew: Immigration, youth, and reactive ethnicity, Applied Developmental Science, 12(2), pp. 108-111.

Schaffer, H. R. (1996) Social Development (Oxford: Blackwell Publishers).

Schulz, W. (2005) Political efficacy and expected participation among lower and upper secondary students. A comparative analysis with data from the IEA Civic Education Study. Paper presented at the European Consortium for Political Research General Conference, Budapest, September 8-10.

Schulz, W., Ainley, J., Fraillon, J., Kerr, D. \& Losito, B. (2010) Initial Findings from the IEA International Civic and Citizenship Education Study (Amsterdam: IEA).

Seif, H. (2010) The civic life of Latina/o immigrant youth: challenging boundaries and creating safe spaces, in: L.R. Sherrod, J. Torney-Purta \& C.A. Flanagan (Eds), Handbook of Research on Civic Engagement in Youth (pp. 445-470) (Hoboken, N.J.: John Wiley \& Sons).

Shingles, R. D. (1981) Black consciousness and political participation: The missing link, American Political Science Review, 75(1), pp. 76-91.

Simon, B., Loewy, M., Sturmer, S., Weber, U., Freytag, P., Habig, C., Kampmeier, C. \& Spahlinger, P. (1998) Collective identification and social movement participation, Journal of Personality and Social Psychology, 74(3), pp. 646-658.

Smith, V. (1996) Employee involvement, involved employees: participative work arrangements in a white-collar service occupation. Social Problems, 43(2), pp. 166179.

Smith, E. S. (1999) The effects of investments in the social capital of youth on political and civic behaviour in young adulthood: A longitudinal analysis, Political Psychology, 20(3), pp. 553-580.

Sobel, R. (1993) From occupational involvement to political participation: an exploratory analysis, Political Behavior, 15(4), pp. 339-353.

Stepick, A. \& Stepick, C. D. (2002) Becoming American, constructing ethnicity: Immigrant youth and civic engagement, Applied Developmental Science, 6(4), pp. 246-257.

Stepick, A., Stepick, C. D. \& Labissiere, Y. (2008) South Florida's immigrant youth and civic engagement: Major engagement: Minor differences, Applied Developmental Science, 12(2), pp. 57-65. 
Theiss-Morse, E. (1993) Conceptualizations of good citizenship and political participation, Political Behavior, 15(4), pp. 355-380.

Torney-Purta, J. (2002) The school's role in developing civic engagement: A study of adolescents in twenty-eight countries, Applied Developmental Science, 6(4), pp. 203212.

Torney-Purta, J. \& Amadeo, J.-A. (2003) A cross-national analysis of political and civic involvement among adolescents, PS: Political Science \& Politics, 36(2), pp. 269-274.

Torney-Purta, J., Barber, C. H. \& Richardson, W. K. (2004) Trust in government-related institutions and political engagement among adolescents in six countries, Acta Politica, 39(4), pp. 380-406.

Torney-Purta, J., Barber, C. H. \& Wilkenfeld, B. (2007) Latino adolescents' civic development in the United States: research results from the IEA Civic Education Study, Journal of Youth and Adolescence, 36(2), pp. 111-125.

Torney-Purta, J., Lehmann, R., Oswald, H. \& Schulz, W. (2001) Citizenship and Education in Twenty-Eight Countries: Civic Knowledge and Engagement at Age Fourteen (Amsterdam: IEA).

Torney-Purta, J., Richardson, W. K. \& Barber, C. H. (2004) Trust in government-related institutions and civic engagement among adolescents: analysis of five countries from the IEA Civic Education Study. CIRCLE Working Paper 17. University of Maryland: Centre for Information and Research on Civic Learning and Engagement (CIRCLE).

van Zomeren, M., Postmes, T. \& Spears, R. (2008) Toward an integrative social identity model of collective action: A quantitative research synthesis of three sociopsychological perspectives, Psychological Bulletin, 134(4), pp. 504-535.

van Zomeren, M., Spears, R., Fischer, A. \& Leach, C. W. (2004) Put your money where your mouth is! Explaining collective action tendencies through group-based anger and group efficacy, Journal of Personality and Social Psychology, 87(5), pp. 649-664.

Verba, S., Schlozman, K. L. \& Brady, H. E. (1995) Voice and Equality: Civic Volunteerism In American Politics (Cambridge, MA: Harvard University Press).

Vertovec, S. (2009) Transnationalism (London: Routledge).

Vráblíková, K. (2013) How context matters? Mobilization, political opportunity structures, and nonelectoral political participation in old and new democracies, Comparative Political Studies, early view published online June 4, 2013.

Wentzel, K. R., \& McNamara, C. C. (1999) Interpersonal relationships, emotional distress and prosocial behaviour in middle school, Journal of Early Adolescence, 19(1), pp. 114-125.

Wolfinger, R. E. \& Rosenstone, S. J. (1980) Who Votes? )(New Haven: Yale University Press.

Wray-Lake, L., Syvertsen, A. K. \& Flanagan, C. A. (2008) Contested citizenship and social exclusion: Adolescent Arab American immigrants' views of the social contract, Applied Developmental Science, 12(2), pp. 84-92.

Yates, M. \& Youniss, J. (1998) Community service and political identity development in adolescence, Journal of Social Issues, 54(3), pp. 495-512.

Youniss, J., McLellan, J., Su, A., \& Yates, M. (1999) The role of community service in identity development: Normative, unconventional, and deviant orientations, Journal of Adolescent Research, 14(2), pp. 248-261.

Youniss, J., McLellan, J. A. \& Yates, M. (1997) What we know about engendering civic identity, American Behavioral Scientist, 40(5), pp. 620-631.

Zaff, J. F., Malanchuk, O. \& Eccles, J. S. (2008) Predicting positive citizenship from adolescence to young adulthood: The effects of a civic context, Applied Developmental Science, 12(1), pp. 38-53. 
Zaff, J. F., Moore, K. A., Papillo, A. R. \& Williams, S. (2003) Implications of extracurricular activity participation during adolescence on positive outcomes, Journal of Adolescent Research, 18(6), pp. 599-630.

Zukin, C., Keeter, S., Andolina, M., Jenkins, K. \& Delli Carpini, M. X. (2006) A New Engagement? Political Participation, Civic Life, and the Changing American Citizen (New York: Oxford University Press). 
Table 1: Some of the different forms of conventional political participation, nonconventional political participation, civic participation, and political and civic engagement.

\section{Forms of conventional political participation}

- Voting

- Membership of a political party

- Running for political election

- Working on political election campaigns for candidates or parties

- Donations to political parties

- Trying to persuade others to vote

\section{Forms of non-conventional political participation}

- Protests, demonstrations, marches

- Signing petitions

- Writing letters/emails to politicians or public officials

- Writing letters/emails/phone calls with a political content to the media (both old and new media)

- Writing articles/blogs with a political content for the media (both old and new media)

- Using social networking sites on the internet to join or like groups which have a political focus

- Using social networking sites on the internet to distribute or share links which have a political content to friends and contacts

- Wearing or displaying a symbol or sign representing support for a political cause

- Distributing leaflets which express support for a political cause

- Participating in fundraising events for a political cause

- Writing graffiti on walls which expresses support for a political cause

- Participating in other illegal actions (e.g., burning a national flag, throwing stones, rioting, etc.) in support of a political cause

- Membership of political lobbying and campaigning organizations/attending meetings of these organizations/expressing one's point of view at these meetings/participating in the activities of these organizations/holding an office in these organizations

\section{Forms of civic participation}

- Informally assisting the well-being of others in the community

- Community problem-solving through community organizations/membership of community organizations/attending meetings of these organizations/expressing one's point of view at these meetings/participating in the activities of these organizations/holding an office in these organizations

- Membership of other non-political organizations (e.g., religious institutions, sports clubs, etc.)/attending meetings of these organizations/expressing one's point of view at these meetings/participating in the activities of these organizations/holding an office in these organizations

- School-based community service

- Undertaking organized voluntary work

- Translation and form-filling assistance for non-native speakers

- Sending remittances to others living elsewhere

- Donations to charities

- Fund-raising activities for good causes 
- Consumer activism: boycotting and buycotting

\section{Forms of political and civic engagement}

- Paying attention to the news media (newspapers, magazines, television, radio, internet)

- Following political or civic affairs

- Having political or civic knowledge or beliefs

- Having political or civic skills

- Understanding political or civic institutions

- Understanding political or civic values

- Holding opinions about, and attitudes towards, political or civic matters

- Having feelings about political or civic matters 
Table 2: Results of the multilevel modelling (based on Brunton-Smith, 2011)

\begin{tabular}{lcccc}
\hline & Voting & $\begin{array}{c}\text { Conventional } \\
\text { participation }\end{array}$ & $\begin{array}{c}\text { Non- } \\
\text { conventional } \\
\text { participation }\end{array}$ & $\begin{array}{c}\text { Civic } \\
\text { participation }\end{array}$ \\
\hline COUNTRY EFFECT & & & & \\
ESS & $7 \%$ & $3 \%$ & $17 \%$ & $25 \%$ \\
ISSP & & $11 \%$ & $22 \%$ & $26 \%$ \\
WVS & $19 \%$ & & & \\
\hline
\end{tabular}

\section{MACRO}

Democratic participation Government efficiency Government accountability Human rights Political stability

Rule of law

$\begin{array}{lccc}\text { NS } & \text { NS } & + & + \\ \text { NS } & + & + & + \\ \text { NS } & + & + & + \\ \text { NS } & + & + & + \\ \text { NS } & + & + & + \\ \text { NS } & + & + & +\end{array}$

\section{$\mathrm{MACRO} \rightarrow \mathrm{MICRO}$}

Democratic participation NS

NS

Gender[+],

Social trust[+] Age [+], Interest and efficacy[-]

Government efficiency NS Gender[+],
Age[+],

Gender(+), Interest and Interest and efficacy[-] efficacy[-]

Accountability NS

Gender[+], Interest and efficacy[-]

Human rights NS

Gender[+] NS Social trust[+]

Political stability

Interest and Interest and Social trust $[+]$ efficacy[-] efficacy[-]

Rule of law NS

Gender[+], Gender[+] Social trust $[+]$ Interest and efficacy[-]

NS Non-significant, +higher score more likely to participate, - higher score less likely to participate, $[+]$ stronger effect, $[-]$ weaker effect 
Figure 1: An integrative model of the macro and social factors driving political and civic participation and engagement (from Barrett, in press)

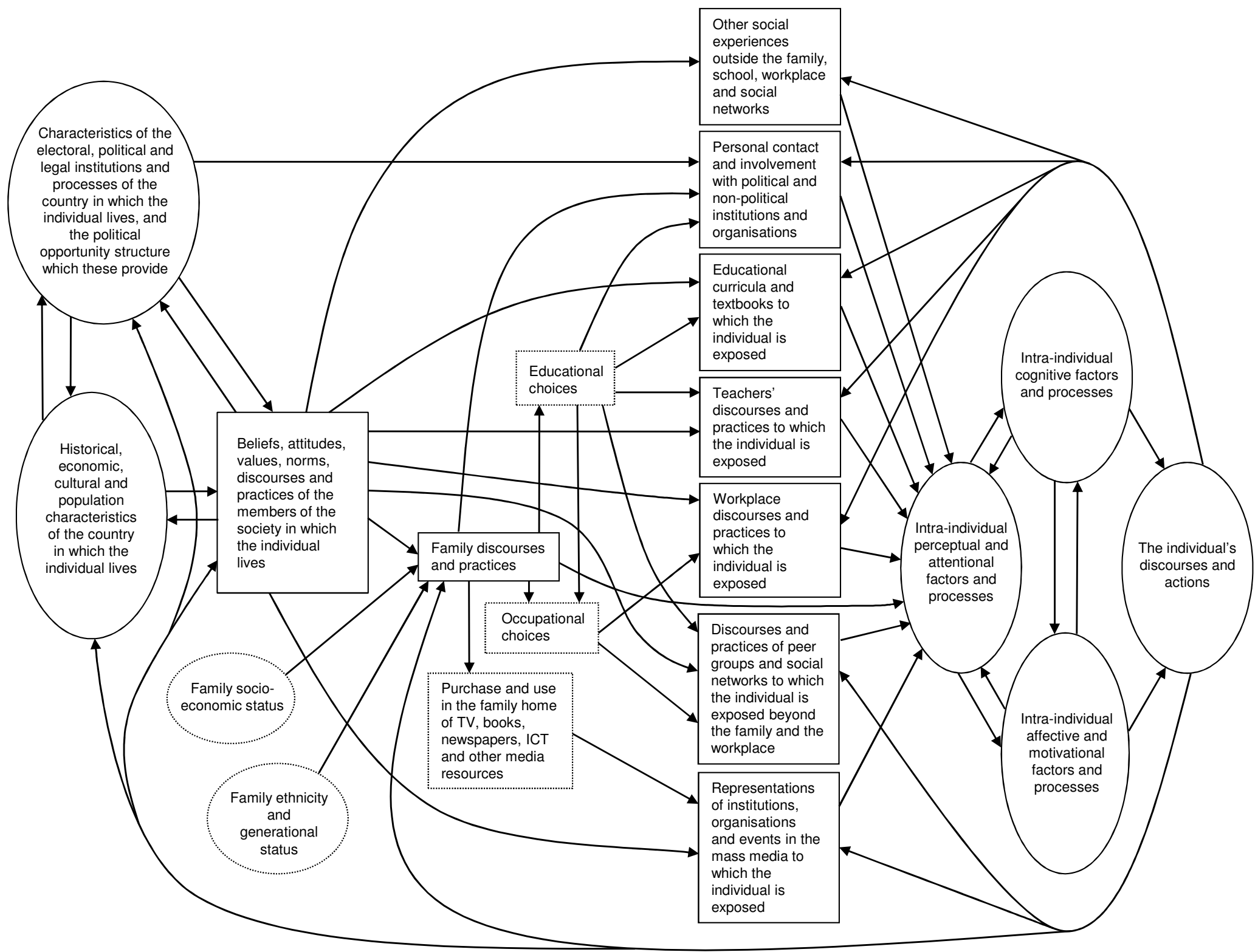


Figure 2: An integrative model of the psychological factors driving political and civic participation (from Barrett, in press)

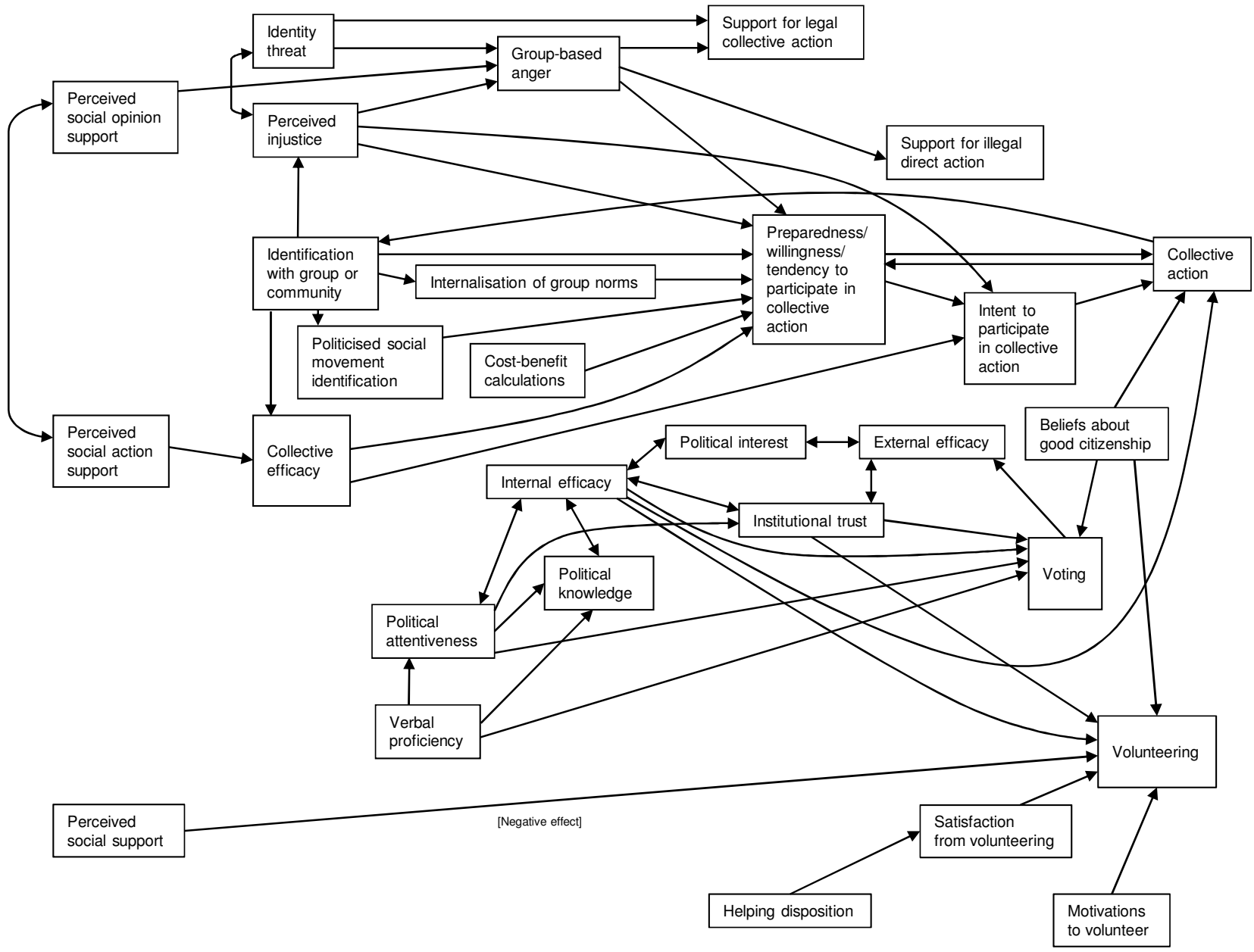


${ }^{1}$ The research reported in this article was supported by a grant received from the European Commission 7 th Framework Programme, FP7-SSH-2007-1, Grant Agreement no: 225282, Processes Influencing Democratic Ownership and Participation (PIDOP).

${ }^{2}$ Full details of the project are available on the PIDOP project website at http://www.fahs.surrey.ac.uk/pidop/ 3 Although proximal social factors were not included within the secondary analyses reported here, their influence was confirmed in the PIDOP project by the new data collected in the participating countries.

${ }^{4}$ For full information about the implications of the findings of the PIDOP project for policy, practice and intervention, interested readers should consult the PIDOP Policy Recommendations document which may be accessed at: http://www.fahs.surrey.ac.uk/pidop/Recommendations.htm 